\title{
Current smoking is associated with a larger waist circumference and a more androgenic profile in young healthy women from high-risk breast cancer families
}

\author{
Carolina Ellberg ${ }^{1,2}\left(\right.$ D $\cdot$ Håkan Olsson $^{1,2} \cdot$ Helena Jernström ${ }^{1}$
}

Received: 13 June 2017 / Accepted: 21 December 2017 / Published online: 3 January 2018

(c) The Author(s) 2018. This article is an open access publication

\begin{abstract}
The purpose was to elucidate the interplay between current smoking, anthropometric measurements, and endogenous hormone levels in women $\leq 40$ years. Questionnaires on lifestyle and reproductive factors were completed by 269 healthy women from high-risk breast cancer families between 1996 and 2006 in Sweden. Blood samples for analyses of plasma testosterone, estradiol, androstenedione, sex hormone-binding globulin, and body measurements were obtained 5-10 days before predicted onset of the next menstrual period. Women without smoking status, who were currently breastfeeding, or using hormonal contraception other than combined oral contraceptives (OCs) were excluded $(n=27)$. Current smokers $(n=57)$ had larger waist circumference $\left(_{\text {adj }} p=0.004\right)$ and waist-to-hip ratio (WHR) $\left(_{\text {adj }} p=0.007\right)$ than non-smokers $(n=185)$. In non-OC users, adjusted mean androstenedione levels were higher in current smokers compared with non-smokers (10.3 vs. $\left.8.6 \mathrm{nmol} / \mathrm{L} ;{ }_{\text {adj }} p=0.0002\right)$. While in current $\mathrm{OC}$ users estradiol levels were higher in smokers compared with non-smokers $\left(22.5\right.$ vs. $\left.17.4 \mathrm{pg} / \mathrm{mL} ;{ }_{\text {adj }} p=0.012\right)$. In multivariable models, WHR was associated with both current smoking $\left(_{\text {adj }} p \leq 0.016\right)$ and higher levels of androstenedione $\left({ }_{\mathrm{adj}} p=0.05\right)$ or bioavailable testosterone $\left({ }_{\mathrm{adj}} p=0.001\right)$. Among non-OC users, a more androgenic profile was observed in current smokers compared with non-smokers, but not in current OC users. Irrespective of OC use, current smoking was associated with increased waist circumference.
\end{abstract}

Keywords Smoking $\cdot$ Testosterone $\cdot$ Oral contraceptives $\cdot$ Androstenedione $\cdot$ Waist-to-hip ratio $\cdot$ Breast cancer

\section{Introduction}

Cigarette smoke is considered a carcinogen, which causes lung cancer as well as several other types of cancer, including pancreatic, liver, ovarian, cervical, and uterine cancers [1]. Whether cigarette smoke causes breast cancer has been heavily debated $[2,3]$. Evidence is suggestive of a causal

Electronic supplementary material The online version of this article (https://doi.org/10.1007/s10552-017-0999-3) contains supplementary material, which is available to authorized users.

Carolina Ellberg

carolina.ellberg@med.lu.se

1 Division of Oncology and Pathology, Department of Clinical Sciences, Lund University and Skåne University Hospital, Lund, Sweden

2 Division of Cancer Epidemiology, Department of Clinical Sciences, Lund University and Skåne University Hospital, Lund, Sweden link in which cigarette smoke influences both breast cancer risk and prognosis $[4,5]$. However, the underlying mechanisms need to be better elucidated. Early oral contraceptive (OC) use is more common among smokers than among non-smokers [6] and may confound the association between smoking and breast cancer risk. Cigarette smoke contains more than 7,000 chemicals, of which 69 are established carcinogens [1]. Furthermore, smoke also acts as an aromatase inhibitor, which may impact the levels of key hormones for breast tissue due to its role in androgen-to-estrogen conversion [1].

An animal study in female baboons showed that administering nicotine at doses equivalent to that of an average smoker inhibited aromatase function by close to $50 \%[7,8]$. Studies in postmenopausal women have indicated increased testosterone levels in current smokers compared with non-smokers [9]. Further, estradiol, testosterone, and sex hormone-binding globulin (SHBG) levels increased with increasing cigarette smoke exposure $[9,10]$. Similarly, there 
are studies that indicate an increase in androstenedione in current smokers [2, 10-15].

In a recent study of breast cancer patients, current smokers, compared with non-smokers, were younger, had a lower body weight and body mass index (BMI), had smaller total breast volume, and had an increased waist-to-hip ratio (WHR). Among aromatase inhibitor-treated patients, current smokers had a threefold increased risk of early recurrence compared with non-smokers [16].

Even though smokers often have lower body weight compared with non-smokers, heavy smoking exposure has been associated with weight gain [17]. Despite the lower weight in light to moderate smokers, there is an increased resistance to insulin in smokers, which might seem counterintuitive [17, 18]. This finding may partly be explained by the fact that smoking is associated with an increase in visceral adipose tissue and WHR [17], even when BMI remains unchanged [19]. Women from high-risk breast cancer families were more likely to have gained weight as of age 20 years and to have a WHR > 0.85 compared with controls. Further women from high-risk breast cancer families were more likely to have given up smoking [20].

Because breast cancer develops long before the tumor is clinically detectable, the purpose of this study was to elucidate the interplay between current smoking and anthropometric measurements, as well as their relationship with endogenous hormone levels in young healthy women, with or without current OC use, at a time point when breast cancer might be initiated.

\section{Materials and methods}

\section{Study population}

Between 1996 and 2006, 269 healthy women $\leq 40$ years old were included in a study of the impact of lifestyle factors on body constitution and hormone levels, as previously described [21-25]. Potential participants were identified from pedigrees and patient charts from high-risk breast cancer families at the Oncogenetic Clinic at Skånes University Hospital, Lund. For families where the person who had been to the Oncogenetic Clinic was not eligible, he or she was asked whether they would be willing to inform relatives of the study. The criteria for being considered belonging to a high-risk breast cancer family if one out of three cases in a family was diagnosed with breast cancer before age 50, if one out of two cases of breast cancer was diagnosed before age 40 , one case of breast cancer was diagnosed before age 30 , had a male relative with a breast cancer diagnosis, or if there was ovarian cancer diagnoses in the family. To be included, the women had to have no previous prophylactic mastectomies or bilateral oophorectomies and no previous cancer diagnoses. Further, the women had to have menstrual cycles because the study visits occurred during cycle days 5-10, as well as 5-10 days prior to the predicted onset of the next menstrual cycle (i.e., days 18-23 in most women). During these visits, a trained research nurse obtained blood samples and body measurements including height, weight, waist and hip circumferences, and breast volume. Breast volumes were calculated as approximated pyramids (base area $\times$ height $/ 3$ ), and measurements were taken when the women were standing on hands and knees. Blood samples were collected between 7:15 am and 12:15 pm. Participants filled out questionnaires on lifestyle and reproductive factors including current and former smoking as well as history of hormonal contraceptive use .

Out of the 269 women in this cohort, 86 (36\%) women belonged to families with a known deleterious BRCA1 mutation, 22 (9\%) belonged to families with a known deleterious BRCA2 mutation, 103 (43\%) belonged to a family where no $B R C A 1 / 2$ mutation was identified, and $30(12 \%)$ of the women belonged to families where no mutation screening had been carried out. All women signed a written informed consent and the Lund University Ethics Committee approved the study.

\section{Laboratory methods}

Laboratory methods for all hormones have been previously described in detail [23]. Testosterone (T) [23], estradiol (E2) [25], and SHBG [25] in EDTA-plasma were measured using electrochemiluminescent immunoassay by an Elecsys 1010/2010 Modular analytics E170 analyzer with a Roche Elecsys 1010/2010 (Roche Diagnostics, Mannheim, Germany). The intra-assay variation was $2.5-6.8 \%$ for testosterone, $1.9-5.7 \%$ for estradiol, and 1.8-4.0\% for SHBG. The limit of detection was $0.069 \mathrm{nmol} / \mathrm{L}$ for testosterone, $5 \mathrm{pg} / \mathrm{mL}$ for estradiol, and $0.35 \mathrm{nmol} / \mathrm{L}$ for SHBG. Androstenedione (4-androsten-3,17-dione) [23] in EDTA-plasma was analyzed with a Coat-A-Count Direct Androstenedione radioimmunoassay in vitro diagnostic test kit (DPC Skafte, Mölndal, Sweden). The maximum allowed variation was $10 \%$ for androstenedione, and the limit of detection was $0.2 \mathrm{nmol} / \mathrm{L}$.

For this study, testosterone (nmol/L) and estradiol (pmol/L) levels were converted to gravimetric units, $\mathrm{pg} / \mathrm{dL}$ and $\mathrm{ng} / \mathrm{L}$, respectively, using a conversion factor of 0.0347 for testosterone and 3.67 for estradiol [26]. The relationship between estradiol and testosterone was investigated using the ratio between the two, which was calculated using the following formula:

$\frac{\mathrm{E} 2}{\mathrm{~T}}=\frac{\mathrm{E} 2(\mathrm{pg} / \mathrm{mL})}{\mathrm{T}(\mathrm{ng} / \mathrm{dL})} \times 10$.

SHBG binds testosterone with high affinity. The remaining testosterone levels are, to some extent, bound by albumin, but with low affinity. The T/SHBG molar ratio was used as a proxy for bioavailable testosterone [27]. 


\section{Statistics}

All analyses were conducted using IBM SPSS statistics version 22.0 [28]. Weight, BMI, breast volume, waist circumference, and plasma hormone levels were not normally distributed and were transformed using the natural logarithm $(\mathrm{Ln})$ to obtain a more normal distribution. Current OC use and smoking status were used as categorical variables. An interaction term between current $\mathrm{OC}$ use and current smoking was calculated in order to assess potential interactions between these exposures on the outcome variables.

Generalized linear models were used to obtain adjusted geometric means with 95\% Wald Confidence Intervals (CI) via estimated marginal means for anthropometric factors and hormonal levels in current smokers and non-smokers. All models investigating anthropometric factors in relation to current smoking status were adjusted for age, nulliparity, and current $\mathrm{OC}$ use. Further, depending on the outcome variable, the models for waist circumference, hip circumference, and WHR were also adjusted for weight and height, the model for weight was also adjusted for WHR and height, the models for height and total breast volume were also adjusted for WHR and weight, and the model for BMI was also adjusted for WHR. A $p$ value $<0.05$ was considered as statistically significant. Nominal $p$ values without adjustment for multiple testing are presented.

\section{Results}

The characteristics of the study population are presented in Table 1. Due to exclusion described in the flowchart in Fig. 1, analyses of the impacts of current smoking on anthropometric factors or hormone levels were conducted for 242 and 229 women, respectively. Included and excluded women were similar with respect to anthropometric and lifestyle factors, and a comparison of included and excluded women is presented in Supplementary Table 1 . The median age at inclusion of the 242 women was 29 years. $46 \%$ were parous and $38 \%$ were current OC

Table 1 Reproductive and anthropometric characteristics by smoking status among women from high-risk breast cancer families, $n=242$

\begin{tabular}{|c|c|c|c|c|c|c|c|c|}
\hline & \multicolumn{2}{|c|}{ All women $(n=242)$} & \multicolumn{2}{|c|}{ Never smokers $(n=140)$} & \multicolumn{2}{|c|}{ Former smokers $(n=45)$} & \multicolumn{2}{|c|}{ Current smokers $(n=57)$} \\
\hline & Median or $n(\%)$ & IQR & Median or $n(\%)$ & IQR & Median or $n(\%)$ & IQR & Median or $n(\%)$ & IQR \\
\hline $\begin{array}{l}\text { Age at inclusion, } \\
\text { years }\end{array}$ & 29 & $24-35$ & 29 & $23-34$ & 31 & $28-37$ & 29 & $25-35$ \\
\hline Year of birth & 1970 & 1964-1976 & 1971 & 1965-1978 & 1967 & 1964-1972 & 1969 & 1963-1974 \\
\hline Age at menarche & $13^{\mathrm{a}}$ & $12-14$ & $13^{\mathrm{a}}$ & $12-14$ & 13 & $12-13$ & 12 & $12-13$ \\
\hline Parous, yes & $112(46)$ & & $60(43)$ & & $26(58)$ & & $26(46)$ & \\
\hline Weight, kg & 64 & $58-74$ & 63 & $57-73$ & 66 & $60-75$ & 65 & $59-74$ \\
\hline Height, cm & 168 & $164-172$ & 168 & $164-172$ & 168 & $165-172$ & 167 & $164-172$ \\
\hline $\begin{array}{l}\text { Body mass index, } \\
\text { BMI }\end{array}$ & 23 & $21-25$ & 22 & $20-25$ & 23 & $21-26$ & 23 & $21-26$ \\
\hline $\begin{array}{l}\text { Waist circumfer- } \\
\text { ence, } \mathrm{cm}\end{array}$ & 76 & $70-83$ & 75 & $69-82$ & 74 & $71-82$ & 78 & $72-84$ \\
\hline $\begin{array}{l}\text { Hip circumference, } \\
\mathrm{cm}\end{array}$ & 101 & $95-106$ & 100 & 94-105 & 102 & $95-106$ & 101 & $95-106$ \\
\hline $\begin{array}{l}\text { Waist-to-hip ratio, } \\
\text { WHR }\end{array}$ & 0.76 & $0.73-0.80$ & 0.75 & $0.72-0.79$ & 0.76 & $0.73-0.78$ & 0.78 & $0.74-0.82$ \\
\hline $\begin{array}{l}\text { Total breast vol- } \\
\text { ume, } \mathrm{cm}^{3}\end{array}$ & $756^{\mathrm{b}}$ & $546-1,101$ & $695^{\mathrm{b}}$ & $493-1,001$ & 748 & $557-1,194$ & 816 & $613-1,195$ \\
\hline $\begin{array}{l}\text { Start age for ever } \\
\text { OC use }\end{array}$ & 17 & $16-18$ & 18 & $16-19$ & 16 & $15-18$ & 16 & $15-17$ \\
\hline $\begin{array}{l}\text { Ever use of OC, } \\
\text { yes }\end{array}$ & $222(92)$ & & $123(88)$ & & 43 (96) & & $56(98)$ & \\
\hline $\begin{array}{l}\text { Current use of OC, } \\
\text { yes }\end{array}$ & $91(38)$ & & $51(36)$ & & $17(38)$ & & $23(40)$ & \\
\hline $\begin{array}{l}\text { Start age for ever } \\
\text { smokers }\end{array}$ & $15^{\mathrm{a}}$ & $14-18$ & & & $17^{\mathrm{a}}$ & 14-19 & 15 & $14-17$ \\
\hline $\begin{array}{l}\text { Time since smok- } \\
\text { ing, years }\end{array}$ & & & & & 4 & $1-10$ & & \\
\hline
\end{tabular}

${ }^{\mathrm{a}}$ Missing data for one woman

${ }^{\mathrm{b}}$ Missing data for two women 


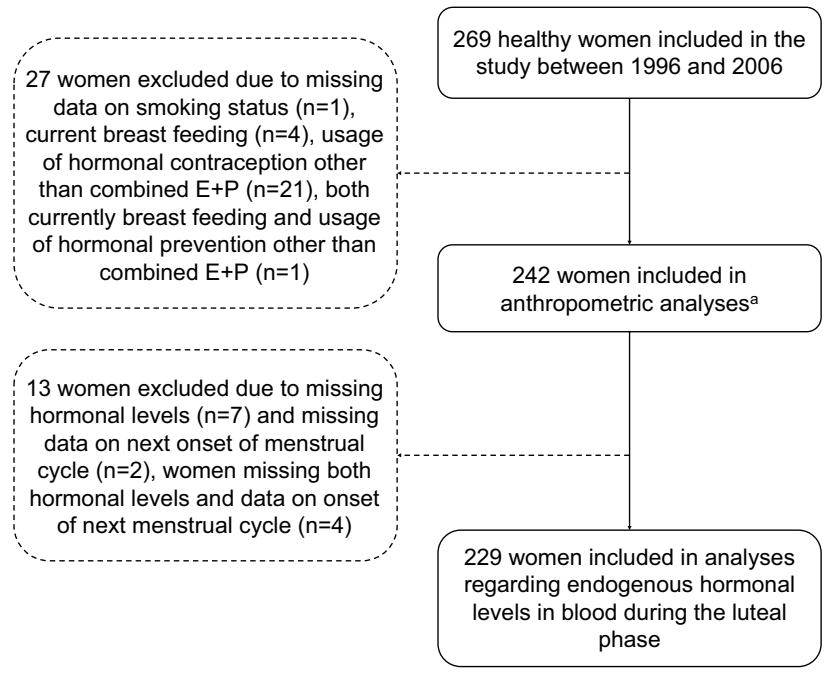

Fig. 1 Flowchart of the inclusion and exclusion criteria for the study. a In analyses of breast volume, two women were excluded due to missing data on breast volume and seven women were excluded due to previous breast operations, leaving 233 included in the analyses

users, whereas $92 \%$ had ever used OCs. $24 \%$ were current smokers, but $42 \%$ reported smoking cigarettes at some point. In women who reported having ever smoked, the median start age was 15 years. Non-smokers contained both former smokers and never smokers, and characteristics for the three groups are displayed in Table 1 for the 242 and 229 women included in the multivariable analyses. Former smokers were slightly older and were more often parous compared with never smokers. Current smokers started smoking at a younger age compared with former smokers, and current and former smokers had a higher frequency of ever using OCs compared with never smokers.

\section{Current smoking status in relation to anthropometric measures}

The impact of current smoking on anthropometric factors was assessed. Since there was no effect modification from current $\mathrm{OC}$ use on the association between current smoking and any of the anthropometric factors, no stratification according to current $\mathrm{OC}$ use was performed. Anthropometric factors in current smokers and non-smokers are presented in Table 2. Compared with non-smokers, current smokers had a significantly larger adjusted mean waist circumference (78.2 vs. $\left.76.5 \mathrm{~cm} ;{ }_{\text {adj }} p=0.004\right)$ and WHR (0.78 vs. 0.76 ; adj $p=0.007)$. No differences between current smokers and non-smokers were observed for hip circumference $\left(_{\text {adj }} p=0.47\right)$, weight $\left({ }_{\text {adj }} p=0.85\right)$, height $\left(_{\text {adj }} p=0.95\right), \mathrm{BMI}$ $\left(_{\text {adj }} p=0.86\right)$, or total breast volume $\left({ }_{\text {adj }} p=0.83\right)$.

\section{Current smoking status in relation to endogenous hormone levels}

Because OCs are known to influence hormone levels, a formal interaction analysis between current $\mathrm{OC}$ use and current smoking for each hormone was performed. There were significant interactions between current smoking and current OC use with respect to estradiol levels $\left(p_{\text {int }}=0.025\right)$ and the $\mathrm{E} 2 / \mathrm{T}$ ratio $\left(p_{\text {int }}=0.024\right)$, but not for the other hormones. Women were stratified according to current OC use. Hormone levels in non-OC users in relation to current smoking are presented in Table 3. Compared with non-smokers, current smokers had higher adjusted mean levels of androstenedione $\left({ }_{\mathrm{adj}} p=0.0002\right)$ and total testosterone $\left({ }_{\mathrm{adj}} p=0.048\right)$, as well as a lower E2/T ratio $\left({ }_{\text {adj }} p=0.027\right)$. No differences between non-smokers and current smokers were observed for bioavailable testosterone, SHBG, or estradiol. Hormone levels in current OC users are presented in Table 4. Current smokers had significantly higher adjusted mean estradiol levels compared with non-smokers $\left({ }_{\text {adj }} p=0.012\right)$. None of the other hormones differed according to current smoking status in OC users.

\section{Impacts of current smoking and hormone levels on WHR}

There was no effect modification between current smoking and current $\mathrm{OC}$ use on WHR. The following mutually adjusted multivariable models investigating the impact of current smoking and hormone levels on WHR were therefore conducted for current OC users and non-OC users combined $(n=229)$. The models were adjusted for age, nulliparity, weight, height, current OC use, and days until the next menstrual period. One hormone per calculation was included because of the high correlation between the measured hormones. These models are presented in Table 5. Current smoking was positively associated with a larger WHR in all models. However, only higher levels of androstenedione $\left(_{\mathrm{adj}} p=0.050\right)$ and bioavailable testosterone $\left(_{\mathrm{adj}} p=0.001\right)$ and lower levels of SHBG $\left(_{\text {adj }} p<0.0001\right)$ were significantly associated with larger WHR.

\section{Discussion}

The main finding of this study was that current smoking was associated with a more androgenic profile in non-OC users, and larger waist circumference and larger WHR irrespective of current OC status. However, in current OC users, estradiol levels were higher in current smokers compared with non-smokers. Even though current smokers had significantly larger waist circumference and higher WHR, they had similar BMI and breast volume compared with non-smokers. 
Table 2 Crude and adjusted geometric means and 95\% CI for anthropometric factors in current smokers and nonsmokers, $n=242$
Table 3 Crude and adjusted geometric means and 95\% CI for hormone levels in non-OC users for current smokers and non-smokers, $n=142$

\begin{tabular}{|c|c|c|c|c|c|c|c|c|c|}
\hline & \multirow[t]{2}{*}{$n$} & \multirow{2}{*}{$\begin{array}{l}\text { Crude } \\
\text { geometric } \\
\text { mean }\end{array}$} & \multicolumn{3}{|c|}{ 95\% Wald CI } & \multirow{2}{*}{$\begin{array}{l}\text { Adj } \\
\text { geometric } \\
\text { mean }\end{array}$} & \multicolumn{3}{|c|}{ 95\% Wald CI } \\
\hline & & & Lower & Upper & $p$ value & & Lower & Upper & $\operatorname{Adj} p$ value \\
\hline \multicolumn{10}{|c|}{ Waist circumference ${ }^{\mathrm{a}, \mathrm{b}, \mathrm{c}}(\mathrm{cm})$} \\
\hline Current smoker & 57 & 79.8 & 76.7 & 82.3 & 0.022 & 78.2 & 77.2 & 79.2 & 0.004 \\
\hline Non-smoker & 185 & 75.9 & 75.2 & 77.5 & & 76.5 & 75.9 & 77.1 & \\
\hline \multicolumn{10}{|c|}{ Hip circumference ${ }^{\mathrm{a}, \mathrm{b}, \mathrm{c}}(\mathrm{cm})$} \\
\hline Current smoker & 57 & 101.8 & 99.6 & 104.1 & 0.36 & 100.7 & 99.9 & 101.5 & 0.47 \\
\hline Non-smoker & 185 & 100.6 & 99.4 & 101.9 & & 101.0 & 100.6 & 101.5 & \\
\hline \multicolumn{10}{|l|}{$\mathrm{WHR}^{\mathrm{a}, \mathrm{b}, \mathrm{c}}$} \\
\hline Current smoker & 57 & 0.79 & 0.77 & 0.80 & 0.004 & 0.78 & 0.77 & 0.79 & 0.007 \\
\hline Non-smoker & 185 & 0.76 & 0.75 & 0.77 & & 0.76 & 0.75 & 0.77 & \\
\hline \multicolumn{10}{|l|}{ Weight $^{\mathrm{a}, \mathrm{c}, \mathrm{d}}(\mathrm{kg})$} \\
\hline Current smoker & 57 & 67.7 & 64.6 & 70.9 & 0.21 & 66.0 & 63.7 & 68.5 & 0.85 \\
\hline Non-smoker & 185 & 65.4 & 63.7 & 67.1 & & 66.3 & 64.9 & 67.7 & \\
\hline \multicolumn{10}{|l|}{ Height $^{\mathrm{a}, \mathrm{b}, \mathrm{d}}(\mathrm{cm})$} \\
\hline Current smoker & 57 & 168.2 & 166.6 & 169.8 & 0.97 & 168.1 & 166.6 & 169.5 & 0.95 \\
\hline Non-smoker & 185 & 168.2 & 167.3 & 169.0 & & 168.1 & 167.3 & 169.9 & \\
\hline \multicolumn{10}{|l|}{$\mathrm{BMI}^{\mathrm{a}, \mathrm{d}}\left(\mathrm{kg} / \mathrm{m}^{2}\right)$} \\
\hline Current smoker & 57 & 24.0 & 22.9 & 25.0 & 0.17 & 23.4 & 22.5 & 24.2 & 0.86 \\
\hline Non-smoker & 185 & 23.1 & 22.6 & 23.7 & & 23.5 & 23.0 & 24.0 & \\
\hline \multicolumn{10}{|c|}{ Total breast volume $\mathrm{e}^{\mathrm{a}, \mathrm{b}, \mathrm{c}, \mathrm{d}}\left(\mathrm{cm}^{3}\right)$} \\
\hline Current smoker & 54 & 818 & 708 & 946 & 0.18 & 741 & 670 & 818 & 0.83 \\
\hline Non-smoker & 179 & 731 & 675 & 792 & & 750 & 709 & 793 & \\
\hline
\end{tabular}

Adjusted for a age, current OC use, and nulliparity, ${ }^{b}$ weight, ${ }^{c}$ height, ${ }^{\mathrm{d}}$ WHR

\begin{tabular}{|c|c|c|c|c|c|c|c|c|c|}
\hline & \multirow[t]{2}{*}{$n$} & \multirow{2}{*}{$\begin{array}{l}\text { Crude } \\
\text { geometric } \\
\text { mean }\end{array}$} & \multicolumn{3}{|c|}{ 95\% Wald CI } & \multirow{2}{*}{$\begin{array}{l}\text { Adj } \\
\text { geometric } \\
\text { mean }\end{array}$} & \multicolumn{3}{|c|}{$95 \%$ Wald CI } \\
\hline & & & Lower & Upper & $p$ value & & Lower & Upper & Adj $p$ value \\
\hline \multicolumn{10}{|c|}{ Androstenedione (nmol/L) } \\
\hline Current smoker & 32 & 10.2 & 9.2 & 11.3 & 0.004 & 10.3 & 9.5 & 11.2 & 0.0002 \\
\hline Non-smoker & 110 & 8.6 & 8.2 & 9.1 & & 8.6 & 8.3 & 9.0 & \\
\hline \multicolumn{10}{|c|}{ Total testosterone (ng/dL) } \\
\hline Current smoker & 32 & 49.6 & 43.1 & 57.1 & 0.14 & 50.9 & 45.1 & 57.6 & 0.048 \\
\hline Non-smoker & 110 & 44.0 & 40.8 & 47.5 & & 44.2 & 41.3 & 47.3 & \\
\hline \multicolumn{10}{|c|}{ T/SHBG molar ratio } \\
\hline Current smoker & 32 & 0.076 & 0.061 & 0.094 & 0.21 & 0.074 & 0.063 & 0.088 & 0.20 \\
\hline Non-smoker & 110 & 0.065 & 0.057 & 0.072 & & 0.065 & 0.060 & 0.072 & \\
\hline \multicolumn{10}{|l|}{ SHBG (nmol/L) } \\
\hline Current smoker & 32 & 22.8 & 19.6 & 26.5 & 0.65 & 23.8 & 21.0 & 27.0 & 0.82 \\
\hline Non-smoker & 110 & 23.7 & 21.8 & 25.7 & & 23.4 & 21.9 & 25.1 & \\
\hline \multicolumn{10}{|l|}{ Estradiol (pg/mL) } \\
\hline Current smoker & 32 & 101.7 & 84.9 & 121.9 & 0.23 & 100.8 & 83.9 & 121.0 & 0.24 \\
\hline Non-smoker & 110 & 115.5 & 104.7 & 127.3 & & 114.1 & 103.1 & 126.2 & \\
\hline \multicolumn{10}{|l|}{$\mathrm{E} 2 / \mathrm{T}$ ratio } \\
\hline Current smoker & 32 & 20.5 & 16.6 & 25.3 & 0.045 & 19.8 & 16.1 & 24.3 & 0.027 \\
\hline Non-smoker & 110 & 26.2 & 23.4 & 29.4 & & 25.8 & 23.0 & 28.9 & \\
\hline
\end{tabular}

Adjusted for age, nulliparity, weight, height, WHR, and days until the next menstrual period 
Table 4 Crude and adjusted geometric means and $95 \% \mathrm{CI}$ for hormone levels in current OC users for current smokers and non-smokers, $n=87$

\begin{tabular}{|c|c|c|c|c|c|c|c|c|c|}
\hline & \multirow[t]{2}{*}{$n$} & \multirow{2}{*}{$\begin{array}{l}\text { Crude } \\
\text { geometric } \\
\text { mean }\end{array}$} & \multicolumn{3}{|c|}{ 95\% Wald CI } & \multirow{2}{*}{$\begin{array}{l}\text { Adj } \\
\text { geometric } \\
\text { mean }\end{array}$} & \multicolumn{3}{|c|}{$95 \%$ Wald CI } \\
\hline & & & Lower & Upper & $p$ value & & Lower & Upper & Adj $p$ value \\
\hline \multicolumn{10}{|c|}{ Androstenedione (nmol/L) } \\
\hline Current smoker & 21 & 6.6 & 5.7 & 7.8 & 0.13 & 5.9 & 5.0 & 6.9 & 0.25 \\
\hline Non-smoker & 66 & 5.8 & 5.3 & 6.3 & & 5.3 & 4.8 & 5.9 & \\
\hline \multicolumn{10}{|c|}{ Total testosterone (ng/dL) } \\
\hline Current smoker & 21 & 31.4 & 26.0 & 37.9 & 0.39 & 28.6 & 23.5 & 34.9 & 0.52 \\
\hline Non-smoker & 66 & 28.5 & 25.6 & 31.7 & & 26.8 & 23.7 & 30.3 & \\
\hline \multicolumn{10}{|c|}{ T/SHBG molar ratio } \\
\hline Current smoker & 21 & 0.016 & 0.012 & 0.021 & 0.35 & 0.016 & 0.012 & 0.021 & 0.39 \\
\hline Non-smoker & 66 & 0.014 & 0.012 & 0.016 & & 0.014 & 0.011 & 0.016 & \\
\hline \multicolumn{10}{|l|}{ SHBG (nmol/L) } \\
\hline Current smoker & 21 & 66.8 & 54.2 & 82.3 & 0.66 & 63.4 & 51.6 & 78.0 & 0.56 \\
\hline Non-smoker & 66 & 70.6 & 62.7 & 79.4 & & 67.7 & 59.5 & 77.0 & \\
\hline \multicolumn{10}{|l|}{ Estradiol (pg/mL) } \\
\hline Current smoker & 21 & 22.2 & 18.5 & 26.6 & 0.027 & 22.5 & 18.7 & 27.1 & 0.012 \\
\hline Non-smoker & 66 & 17.5 & 15.8 & 19.4 & & 17.4 & 15.5 & 19.6 & \\
\hline \multicolumn{10}{|l|}{$\mathrm{E} 2 / \mathrm{T}$ ratio } \\
\hline Current smoker & 21 & 7.1 & 5.7 & 8.8 & 0.27 & 7.9 & 6.2 & 9.9 & 0.14 \\
\hline Non-smoker & 66 & 6.1 & 5.4 & 6.9 & & 6.5 & 5.6 & 7.5 & \\
\hline
\end{tabular}

Adjusted for age, nulliparity, weight, height, WHR, and days until the next menstrual period
It needs to be mentioned that this population was generally slim, so, despite the increase in WHR or waist circumference in smokers, most women had a WHR within the recommended WHO limits. However, in a recent study by Iyengar et al. [29], even small changes in body constitution in a normal weight breast cancer high-risk population can be related to the presence of breast white adipose tissue inflammation. Metabolically, these women present with an obese phenotype in terms of inflammation and aromatase activity, despite being within the recommended limits of BMI [29]. The observed difference in body fat distribution towards more abdominal fat in relation to androstenedione and testosterone suggests that current smoking in the present cohort was associated with a more inflammatory and/ or androgenic profile at the age when breast cancer is likely to be initiated.

It has been suggested that smoking may induce hyperandrogenism in premenopausal women [30], and that it may increase the levels of testosterone and androstenedione in postmenopausal women [2]. Both testosterone and androstenedione levels have been implicated as breast cancer risk factors in pre- and postmenopausal women [1, 2, 15, 31, 32]. In the present study, increased androstenedione and testosterone levels were observed in current smokers who were non-OC users, indicating that current smoking might be a contributing factor to the increase in androgens. Nicotine also acts as an aromatase inhibitor, which may partly explain the androgenic profile [2]. Furthermore, this increase in androgen levels might be related to increasing WHR. With regard to the increased estradiol levels in current smokers using OCs, we hypothesized that there were two plausible explanations: one explanation is that there is reduced efficacy of OCs while currently smoking [33]; the other explanation is lower adherence to taking the pill because smokers have been reported to have lower adherence to taking medication [34, 35].

With regard to baseline characteristics, the included and excluded women were similar, suggesting that the exclusion of some women was unlikely to introduce bias. The prevalence of smokers in the study population used in the present study resembles the population with regard to the number of smokers [36], and the prevalence of smokers and ever smokers was similar in women who were excluded due to missing data on hormone levels or anthropometric measures. Moreover, all anthropometric measures used in the present study were obtained by a trained nurse. The present study is somewhat limited with regard to population size, which limits the possibility for stratification, such as by dose of cigarettes per day.

The group of non-smokers includes both never smokers and former smokers. These groups were slightly different with respect to age, parity, and BMI. The main reason for combining former and never smokers was that the aim of the study was to elucidate the impact of current smoking in young women on hormone levels and anthropometrics. The slightly higher age along with the higher parity among former smokers compared with never smokers is most likely explained by women quitting smoking before 
Table 5 Mutually adjusted multivariable models of the impacts of current smoking and hormone levels on Ln-transformed WHR, $n=229$

\begin{tabular}{|c|c|c|c|c|}
\hline & \multirow[t]{2}{*}{$\beta$} & \multicolumn{2}{|c|}{ 95\% Wald CI } & \multirow[t]{2}{*}{$p$ value } \\
\hline & & Lower & Upper & \\
\hline Intercept & 0.214 & 0.023 & 0.405 & 0.028 \\
\hline $\begin{array}{l}\text { Androstenedione } \\
\mathrm{Ln}(\mathrm{nmol} / \mathrm{L})\end{array}$ & 0.021 & -0.000013 & 0.043 & 0.050 \\
\hline Current smoker, yes & 0.018 & 0.003 & 0.033 & 0.016 \\
\hline Weight LN(kg) & 0.183 & 0.143 & 0.224 & $<0.0001$ \\
\hline Height (cm) & -0.002 & -0.003 & -0.001 & 0.003 \\
\hline Intercept & 0.234 & 0.038 & 0.430 & 0.019 \\
\hline $\begin{array}{l}\text { Total testosterone } \\
\text { Ln(ng/dL) }\end{array}$ & 0.004 & -0.012 & 0.019 & 0.662 \\
\hline Current smoker, yes & 0.021 & 0.007 & 0.036 & 0.004 \\
\hline Weight Ln(kg) & 0.195 & 0.156 & 0.235 & $<0.0001$ \\
\hline Height (cm) & -0.002 & -0.003 & -0.001 & 0.001 \\
\hline Intercept & 0.314 & 0.125 & 0.504 & 0.001 \\
\hline T/SHBG molar ratio & 0.018 & 0.008 & 0.028 & 0.001 \\
\hline Current smoker, yes & 0.019 & 0.005 & 0.033 & 0.009 \\
\hline Weight Ln(kg) & 0.171 & 0.131 & 0.212 & $<0.0001$ \\
\hline Height (cm) & -0.001 & -0.003 & -0.0004 & 0.009 \\
\hline Intercept & 0.345 & 0.160 & 0.539 & 0.0003 \\
\hline SHBG Ln(nmol/L) & -0.029 & -0.043 & -0.016 & $<0.0001$ \\
\hline Current smoker, yes & 0.020 & -0.00 & 0.034 & 0.004 \\
\hline Weight $\operatorname{Ln}(\mathrm{kg})$ & 0.174 & 0.135 & 0.212 & $<0.0001$ \\
\hline Height $(\mathrm{cm})$ & -0.002 & -0.003 & -0.0004 & 0.007 \\
\hline Intercept & 0.255 & 0.056 & 0.454 & 0.012 \\
\hline E2 $\mathrm{Ln}(\mathrm{pg} / \mathrm{mL})$ & -0.002 & -0.014 & 0.010 & 0.749 \\
\hline Current smoker, yes & 0.021 & 0.007 & 0.036 & 0.004 \\
\hline Weight Ln(kg) & 0.198 & 0.160 & 0.237 & $<0.0001$ \\
\hline Height (cm) & -0.002 & -0.003 & -0.001 & 0.001 \\
\hline Intercept & 0.258 & 0.0063 & 0.452 & 0.009 \\
\hline $\mathrm{E} 2 / \mathrm{T}$ ratio & -0.00 & -0.014 & 0.008 & 0.563 \\
\hline Current smoker, yes & 0.021 & 0.007 & 0.036 & 0.004 \\
\hline Weight $\operatorname{Ln}(\mathrm{kg})$ & 0.197 & 0.158 & 0.235 & $<0.0001$ \\
\hline Height (cm) & -0.002 & -0.003 & -0.001 & 0.001 \\
\hline
\end{tabular}

Additionally, all models were adjusted for age, nulliparity, current OC use, and days until the next menstrual period

or when getting pregnant. Analyses were performed with stratification according to smoking status (as in never, ever, and former smokers) and the results remained essentially the same (data not shown). The women all came from high-risk families, and analyses were also performed after stratification based on mutation status to make sure that results were not associated with mutations in the BRCA1/2 genes, but it did not alter the results (data not shown).

Regarding hormone levels, if more sensitive methods had been available at the time of analyses, such as those available today, it is possible that the results among current OC users with respect to hormone levels in current smokers and non-smokers could have been different because several of the current OC users had low hormone levels. However, the findings are similar to other observations [2] and it is therefore unlikely that this issue had a significant impact on our results.

Taken together, we have observed associations between current smoking and different risk factors for breast cancer in young healthy women from high-risk breast cancer families at the age when breast cancer might be initiated. Current smoking was associated with increased WHR, which is a risk factor for increased inflammation or even a metabolically obese phenotype [17], and increased levels of androgens such as testosterone and androstenedione, which are implicated as risk factors for breast cancer and hyperandrogenism [32]. We propose that smoking needs to be taken into account when studying the relationship between these factors. Because many of the BRCA1/2 mutation carriers in our cohort had undergone prophylactic surgery after inclusion in the study, there were too few cases of breast cancer for a meaningful comparison of the breast cancer risk between current smokers and non-smokers. Breast cancer risk in relation to smoking, OC use, anthropometric factors, and hormone levels needs to be studied in another substantially larger cohort.

\section{Conclusion}

In conclusion, we found that among non-OC users, current smokers had more androgenic profile, mainly driven by increased androstenedione levels, compared with nonsmokers. In current OC users, higher estradiol levels were found among current smokers compared with non-smokers. Irrespective of $\mathrm{OC}$ use, current smoking was associated with increased waist circumference. History of OC use should be considered in studies of smoking in women.

Acknowledgments The authors would like to thank research nurses Kerstin Nilsson, Monica Pehrsson, Karin Henriksson, and Anita Schmidt-Zander for data collection and statistician Dr. Per Broberg for assistance with the generalized linear models. This study was supported by grants from the Swedish Cancer Society, the Medical Faculty, Lund University, the Mrs. Berta Kamprad's Foundation, and ERC Advanced Grant 2011 (Advanced Grant ERC-2011-294576).

Open Access This article is distributed under the terms of the Creative Commons Attribution 4.0 International License (http://creativecommons.org/licenses/by/4.0/), which permits unrestricted use, distribution, and reproduction in any medium, provided you give appropriate credit to the original author(s) and the source, provide a link to the Creative Commons license, and indicate if changes were made. 


\section{References}

1. (2010). In: How tobacco smoke causes disease: the biology and behavioral basis for smoking-attributable disease: a Report of the Surgeon General. Publications and Reports of the Surgeon General. Atlanta (GA), https://www.ncbi.nlm.nih.gov/books/ NBK53017/

2. (2014). In: The health consequences of smoking-50 years of progress: A Report of the Surgeon General. Reports of the Surgeon General. Atlanta (GA), https://www.ncbi.nlm.nih.gov/books/ NBK179276/

3. Ewertz M (1990) Smoking and breast cancer risk in Denmark. Cancer Causes Control 1(1):31-37

4. Gaudet MM, Carter BD, Brinton LA, Falk RT, Gram IT, Luo J, Milne RL, Nyante SJ, Weiderpass E, Beane Freeman LE, Sandler DP, Robien K, Anderson KE, Giles GG, Chen WY, Feskanich D, Braaten T, Isaacs C, Butler LM, Koh WP, Wolk A, Adami HO, White E, Margolis KL, Thun MJ, Gapstur SM (2016) Pooled analysis of active cigarette smoking and invasive breast cancer risk in 14 cohort studies. Int J Epidemiol. https://doi.org/10.1093/ ije/dyw 288

5. Reynolds P (2013) Smoking and breast cancer. J Mammary Gland Biol Neoplas 18(1):15-23. https://doi.org/10.1007/ s10911-012-9269-x

6. Jernström H, Loman N, Johannsson OT, Borg Å, Olsson H (2005) Impact of teenage oral contraceptive use in a population-based series of early-onset breast cancer cases who have undergone BRCA mutation testing. Eur J Cancer 41(15):2312-2320. https:// doi.org/10.1016/j.ejca.2005.03.035

7. Biegon A, Kim SW, Logan J, Hooker JM, Muench L, Fowler JS (2010) Nicotine blocks brain estrogen synthase (aromatase): in vivo positron emission tomography studies in female baboons. Biol Psychiatry 67(8):774-777. https://doi.org/10.1016/j. biopsych.2010.01.004

8. Biegon A, Alia-Klein N, Fowler JS (2012) Potential contribution of aromatase inhibition to the effects of nicotine and related compounds on the brain. Front Pharmacol 3:185. https://doi. org/10.3389/fphar.2012.00185

9. Brand JS, Chan MF, Dowsett M, Folkerd E, Wareham NJ, Luben RN, van der Schouw YT, Khaw KT (2011) Cigarette smoking and endogenous sex hormones in postmenopausal women. J Clin Endocrinol Metab 96(10):3184-3192. https://doi.org/10.1210/ jc.2011-1165

10. Kapoor D, Jones TH (2005) Smoking and hormones in health and endocrine disorders. Eur J Endocrinol 152(4):491-499. https:// doi.org/10.1530/eje.1.01867

11. Kaaks R, Berrino F, Key T, Rinaldi S, Dossus L, Biessy C, Secreto G, Amiano P, Bingham S, Boeing H, Bueno de Mesquita HB, Chang-Claude J, Clavel-Chapelon F, Fournier A, van Gils CH, Gonzalez CA, Gurrea AB, Critselis E, Khaw KT, Krogh V, Lahmann PH, Nagel G, Olsen A, Onland-Moret NC, Overvad K, Palli D, Panico S, Peeters P, Quiros JR, Roddam A, Thiebaut A, Tjonneland A, Chirlaque MD, Trichopoulou A, Trichopoulos D, Tumino R, Vineis P, Norat T, Ferrari P, Slimani N, Riboli E (2005) Serum sex steroids in premenopausal women and breast cancer risk within the European Prospective Investigation into Cancer and Nutrition (EPIC). J Natl Cancer Inst 97(10):755-765. https://doi.org/10.1093/jnci/dji132

12. Longcope C, Johnston CC Jr (1988) Androgen and estrogen dynamics in pre- and postmenopausal women: a comparison between smokers and nonsmokers. J Clin Endocrinol Metab 67(2):379-383. https://doi.org/10.1210/jcem-67-2-379

13. Manjer J, Johansson R, Lenner P (2005) Smoking as a determinant for plasma levels of testosterone, androstenedione, and DHEAs in postmenopausal women. Eur J Epidemiol 20(4):331-337
14. Soldin OP, Makambi KH, Soldin SJ, O’Mara DM (2011) Steroid hormone levels associated with passive and active smoking. Steroids 76(7):653-659. https://doi.org/10.1016/j. steroids.2011.02.042

15. Endogenous H, Breast Cancer Collaborative G, Key TJ, Appleby PN, Reeves GK, Travis RC, Alberg AJ, Barricarte A, Berrino F, Krogh V, Sieri S, Brinton LA, Dorgan JF, Dossus L, Dowsett M, Eliassen AH, Fortner RT, Hankinson SE, Helzlsouer KJ, Hoff man-Bolton J, Comstock GW, Kaaks R, Kahle LL, Muti P, Overvad K, Peeters PH, Riboli E, Rinaldi S, Rollison DE, Stanczyk FZ, Trichopoulos D, Tworoger SS, Vineis P (2013) Sex hormones and risk of breast cancer in premenopausal women: a collaborative reanalysis of individual participant data from seven prospective studies. Lancet Oncol 14(10):1009-1019. https://doi.org/10.1016/S1470-2045(13)70301-2

16. Persson M, Simonsson M, Markkula A, Rose C, Ingvar C, Jernström H (2016) Impacts of smoking on endocrine treatment response in a prospective breast cancer cohort. Br J Cancer 115(3):382-390. https://doi.org/10.1038/bjc.2016.174

17. Chiolero A, Faeh D, Paccaud F, Cornuz J (2008) Consequences of smoking for body weight, body fat distribution, and insulin resistance. Am J Clin Nutr 87(4):801-809

18. Tweed JO, Hsia SH, Lutfy K, Friedman TC (2012) The endocrine effects of nicotine and cigarette smoke. Trends Endocrinol Metab 23(7):334-342. https://doi.org/10.1016/j. tem.2012.03.006

19. Berlin I (2008) Smoking-induced metabolic disorders: a review. Diabetes Metab 34(4 Pt 1):307-314. https://doi.org/10.1016/j. diabet.2008.01.008

20. Harvie MN, Bokhari S, Shenton A, Ashcroft L, Evans G, Swindell R, Howell A (2007) Adult weight gain and central obesity in women with and without a family history of breast cancer: a case control study. Fam Cancer 6(3):287-294. https://doi.org/10.1007/ s10689-007-9122-3

21. Hietala M, Olsson H, Jernström H (2008) Prolactin levels, breastfeeding and milk production in a cohort of young healthy women from high-risk breast cancer families: implications for breast cancer risk. Fam Cancer 7(3):221-228. https://doi.org/10.1007/ s10689-007-9178-0

22. Henningson M, Hietala M, Törngren T, Olsson H, Jernström H (2011) IGF1 htSNPs in relation to IGF-1 levels in young women from high-risk breast cancer families: implications for earlyonset breast cancer. Fam Cancer 10(2):173-185. https://doi. org/10.1007/s10689-010-9404-Z

23. Hietala M, Henningson $M$, Törngren $T$, Olsson $H$, Jernström $H$ (2011) Androgen receptor htSNPs in relation to androgen levels and $\mathrm{OC}$ use in young women from high-risk breast cancer families. Mol Genet Metabol 102(1):82-90. https://doi.org/10.1016/j. ymgme.2010.09.006

24. Rosendahl AH, Hietala M, Henningson M, Olsson H, Jernström H (2011) IGFBP1 and IGFBP3 polymorphisms predict circulating IGFBP-3 levels among women from high-risk breast cancer families. Breast Cancer Res Treat 127(3):785-794. https://doi. org/10.1007/s10549-010-1277-1

25. Jernström H, Henningson M, Johansson U, Olsson H (2008) Coffee intake and CYP1A2*1F genotype predict breast volume in young women: implications for breast cancer. Br J Cancer 99(9):1534-1538. https://doi.org/10.1038/sj.bjc.6604687

26. SI units https://www.questdiagnostics.com/dms/Documents/testcenter/si_units.pdf. Accessed 17 May 2017

27. Vermeulen A, Verdonck L, Kaufman JM (1999) A critical evaluation of simple methods for the estimation of free testosterone in serum. J Clin Endocrinol Metab 84(10):3666-3672. https://doi. org/10.1210/jcem.84.10.6079

28. IBM Corp (2013) IBM SPSS Statistics for Windows, Version 22.0. IBM Corp., Armonk 
29. Iyengar NM, Brown KA, Zhou XK, Gucalp A, Subbaramaiah K, Giri DD, Zahid H, Bhardwaj P, Wendel NK, Falcone DJ, Wang H, Williams S, Pollak M, Morrow M, Hudis CA, Dannenberg AJ (2017) Metabolic obesity, adipose inflammation and elevated breast aromatase in women with Normal Body Mass Index. Cancer Prev Res. https://doi.org/10.1158/1940-6207.CAPR-16-0314

30. Duskova M, Simunkova K, Hill M, Velikova M, Kubatova J, Kancheva L, Kazihnitkova H, Hruskovicova H, Pospisilova H, Racz B, Salatova M, Cirmanova V, Kralikova E, Starka L, Parizek A (2012) Chronic cigarette smoking alters circulating sex hormones and neuroactive steroids in premenopausal women. Physiol Res 61(1):97-111

31. Key TJ, Appleby PN, Reeves GK, Travis RC, Brinton LA, Helzlsouer KJ, Dorgan JF, Gapstur SM, Gaudet MM, Kaaks R, Riboli E, Rinaldi S, Manjer J, Hallmans G, Giles GG, Le Marchand L, Kolonel LN, Henderson BE, Tworoger SS, Hankinson SE, Zeleniuch-Jacquotte A, Koenig K, Krogh V, Sieri S, Muti P, Ziegler RG, Schairer C, Fuhrman BJ, Barrett-Connor E, Laughlin GA, Grant EJ, Cologne J, Ohishi W, Hida A, Cauley JA, Fourkala EO, Menon U, Rohan TE, Strickler HD, Gunter MJ, Endogenous H, Breast Cancer Collaborative G (2015) Steroid hormone measurements from different types of assays in relation to body mass index and breast cancer risk in postmenopausal women: reanalysis of eighteen prospective studies. Steroids 99 (Pt A):49-55. https:// doi.org/10.1016/j.steroids.2014.09.001

32. Kaaks R, Tikk K, Sookthai D, Schock H, Johnson T, Tjonneland A, Olsen A, Overvad K, Clavel-Chapelon F, Dossus L, Baglietto L, Rinaldi S, Chajes V, Romieu I, Boeing H, Schutze M,
Trichopoulou A, Lagiou P, Trichopoulos D, Palli D, Sieri S, Tumino R, Ricceri F, Mattiello A, Buckland G, Ramon Quiros J, Sanchez MJ, Amiano P, Chirlaque MD, Barricarte A, Bas Buenode-Mesquita H, van Gils CH, Peeters PH, Andersson A, Sund M, Weiderpass E, Khaw KT, Wareham N, Key TJ, Travis RC, Merritt MA, Gunter MJ, Riboli E, Lukanova A (2014) Premenopausal serum sex hormone levels in relation to breast cancer risk, overall and by hormone receptor status-results from the EPIC cohort. Int J Cancer 134(8):1947-1957. https://doi.org/10.1002/ijc.28528

33. Rosenberg MJ, Waugh MS, Stevens CM (1996) Smoking and cycle control among oral contraceptive users. Am J Obstet Gynecol 174(2):628-632

34. Markkula A, Hietala M, Henningson M, Ingvar C, Rose C, Jernström H (2012) Clinical profiles predict early nonadherence to adjuvant endocrine treatment in a prospective breast cancer cohort. Cancer Prev Res 5(5):735-745. https://doi. org/10.1158/1940-6207.CAPR-11-0442

35. Komenaka IK, Hsu CH, Martinez ME, Bouton ME, Low BG, Salganick JA, Nodora J, Hibbard ML, Jha C (2011) Preoperative chemotherapy for operable breast cancer is associated with better compliance with adjuvant therapy in matched stage II and IIIA patients. Oncologist 16(6):742-751. https://doi.org/10.1634/ theoncologist.2010-0266

36. (Folkhälsoinsitutet) The Public Health Agency of Sweden (2017) Tobaksvanor (Tobacco use). Folkhälsoinsitutet. https:// www.folkhalsomyndigheten.se/folkhalsorapportering-statistik/ statistikdatabaser-och-visualisering/nationella-folkhalsoenkaten/ levnadsvanor/tobaksvanor/ 